\title{
Evaluation of the Effectiveness of the Online Teaching and Learning Process at the University: Based on Kirkpatrick's Model
}

\author{
Imriani Moroki \\ Institut Agama Kristen Negeri Manado \\ imriani.moroki@gmail.com
}

\begin{abstract}
The industrial revolution 4.0 is an era where humans can enjoy the ease of doing many things. However, it is undeniable that the development of technology and information in this era also resulted in world disruption or the disruptive era. In the disruptive era, students get easier access to information, more global networks, and shift from teacher-centered or one-way learning to two-way learning. Besides, this disruptive era is characterized by the use of social media platforms for communication and no seniority level in looking at other students. Even, some emerging innovations with advanced technology provide better access to information and sources of knowledge from anywhere and anytime without having to attend a class. In responding to changes in the disruptive era by utilizing the development of technology and information, many lecturers as educators have transformed the traditional learning process into an online learning process. However, it does not mean that the online learning process does not encounter obstacles or runs smoothly without any deficiencies in its implementation. Therefore, evaluation should be considered to find out the value of a program or system that is implemented/applied. This study aims to evaluate the effectiveness of online teaching and learning process, to analyze the strengths and weaknesses of the online learning process, and to evaluate the achievement of learning objectives, particularly in IAKN Manado. This study uses Kirkpatrick's evaluation model which consists of 4 levels with different measurements/assessments at each level. At level 1, the reaction level, the study used a questionnaire distributed to 100 students and analyzed the satisfaction level using the Customer Satisfaction Index (CSI). The result shows that the satisfaction level of students on the online learning process reaches $71 \%$, or in other words, it is in the dissatisfied level. At level 2, the learning level, it analyzed the results of pre-test and post-test before and after the students participated in online learning. Then, based on the Wilcoxon Signed Rank test, the $\mathrm{z}$ value is -8.363 with a p-value (Asymp. Sig. 2-tailed) of 0.000 which is less than the critical limit value of 0.05 . Therefore, $\mathrm{H}_{1}$ is accepted meaning that there are significant differences between the pre-test and post-test groups. At level 3, the potential of behavior change level, the data were obtained from interviews with 2 lecturers who have conditional courses with previous courses using online learning. The data were also collected from lecturer observations about changes in student behavior including changes in mindset, knowledge, and utilization of skills and knowledge after the online learning process. At this level, the researcher also distributed questionnaires (categorical statements) with Guttman scale analysis to 100 sample students. The result of level 3 shows that students' behavior that follows the online learning process almost changes. It means that the behavior changes are not felt thoroughly and optimally. At level 4, the result level, the data used were the final results of the online learning process. The result shows that it reaches a satisfactory level. Thus, based on all four levels, it can be concluded that the online learning process is not effective yet. Some components of the online learning process need to be optimized to make the learning run effectively and to achieve the learning objectives. Supporting facilities and the skills of lecturers as educators in creating and presenting creative, effective, and fun learning strategies, models, and methods are essential components of the learning process. This study is
\end{abstract}


expected to provide references to those who carry out the online learning process, particularly lecturers to be able to choose the correct strategies, models, and methods to create an effective learning process, to achieve learning objectives, and to improve competencies and skills of lecturers in implementing the online learning process to be more flexible and to get better results in the future.

Keywords: Online learning process, Evaluation, Kirkpatrick's model.

\section{Introduction}

World development provides both positive and negative impacts. The impact does not necessarily result from the development itself, but also depend on the human as the actor of the development. It is marked by the development of technology and information that brought us into the industrial revolution 4.0.

The industrial revolution 4.0 is an era where humans can enjoy the ease of doing many things including through the help of the internet, which known as IoT (internet of things), for example, controlling our financial activities anywhere and anytime, learning from experts without having to meet face to face, or establish relationships and hold meetings through applications in our internet-based devices.

It is undeniable that the development of technology and information in the industrial revolution 4.0 also resulted in world disruption or the disruptive era. The disruptive era is a period where many there are innovations that are not predicted and realized by institutions, organizations, agencies, or companies that can disrupt or even destroy the existing system. The traditional system is replaced by a new all-digital system.

In responding to the disruptive era, colleges/universities should be able to organize education by adjusting facilities to suit the students' needs. The impact of the disruptive era in the millennial generation today makes the learning process different from the previous generation. In the disruptive era, students have better access to information and more global networks and shift from teacher-centered or one-way learning to two-way learning that demands the lecturers as educators to improve their teaching competencies and skills. In addition, this disruptive era is characterized by the use of social media platforms for communication and no seniority level in looking at other students.

In this disruptive era, a number of emerging innovations with advanced technology provides better access to information and sources of knowledge from anywhere and anytime without having to attend a class. But lecturers of educators cannot forget their responsibilities as a leader who navigates, directs and regulates the learning process in a class so that learning objectives can be achieved without ignoring changes in learning conditions caused by the disruptive era.

In responding to changes in the disruptive era by utilizing the development of technology and information, many lecturers as educators have transformed the traditional learning process into an online learning process. However, it does not mean that the online learning process does not encounter obstacles or runs smoothly without any deficiencies in its implementation. Therefore, evaluation should be considered to find out the value of a program or system that is implemented/applied. In addition, the evaluation aims to find both weaknesses that can be minimized or eliminated, and strengths that can be improved or maintained from a program or 
system that has been implemented or carried out. It drives the author to conduct research on evaluating the effectiveness of the online teaching and learning process at the university.

This research aims to evaluate the effectiveness of the online teaching and learning process, to analyze the strengths and weaknesses of the online learning process, and to evaluate the achievement of learning objectives. Therefore, this research can be used as a theoretical reference in evaluating the use of effective learning methods to achieve learning objectives.

\section{Research Method}

This research uses some approaches including quantitative and qualitative, and evaluative descriptive methods. The quantitative approach and descriptive evaluative method were selected as they are the most suitable approach and method for presenting results effectively and interpreting results accurately. This method was to evaluate the effectiveness of the online learning process and the achievement of learning objectives and to interpret the results of the analysis in the form of numbers, documentation, verbal and non-verbal statements, notes, and other data such as tables or graphs. The qualitative approach was used at one of the 4 levels proposed by Kirk Patrick because the level required qualitative than quantitative approach. The population of this study was students of Institut Agama Kristen Negeri Manado with 100 students and 2 conditional lecturers as samples. The instrument for data collection consisted of questionnaires, students' scores, observation checklists, and interviews. Moreover, this study used the pretest-posttest scores and final scores after the students participated in online learning. This study also used the Kirkpatrick model as presented in Figure 1.

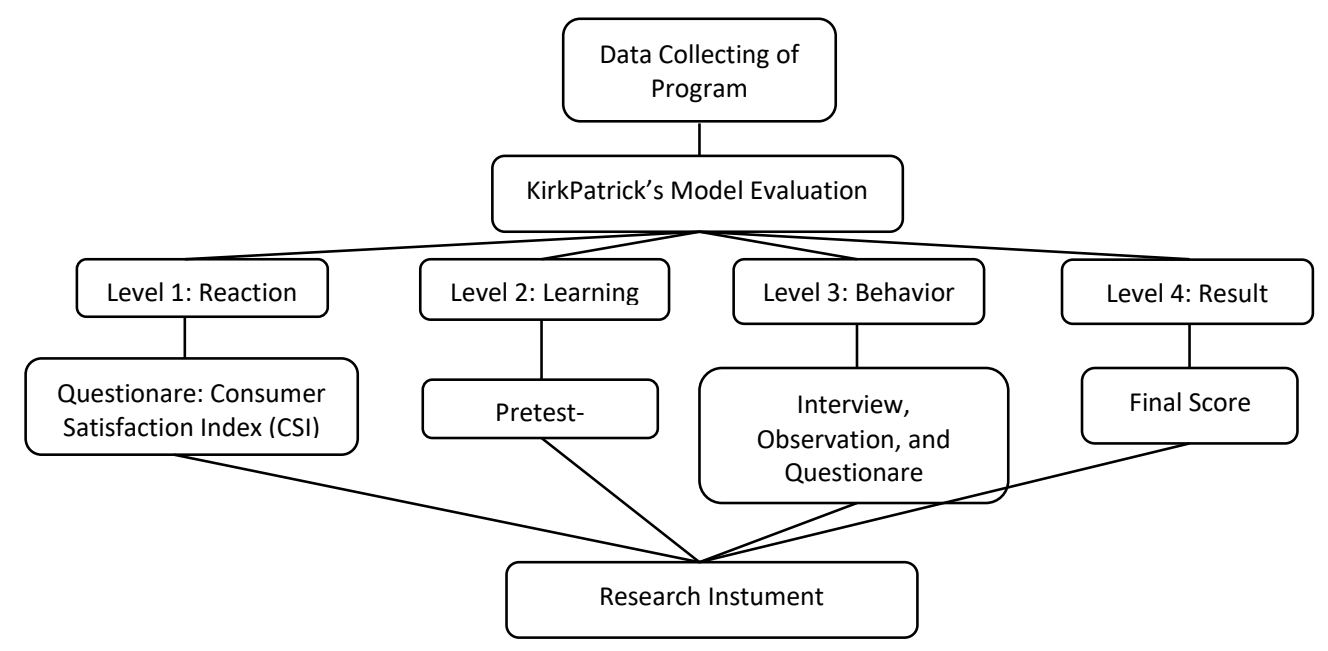

Fig.1. Implementation of KirkPatrick's Evaluation Model 
Data were collected from each level ofevaluation of the Kirkpatrick's Model. In this study, each level used its assessment as presented in Figure 1 above. Evaluation of the effectiveness of the online learning process was carried out in four levels, namely the Reaction Level, Learning Level, potential of behavior change level, and Result Level.

\section{Result and Discussion}

The Kirkpatrick's Model was used to evaluate the effectiveness of the online learning process at Institut Agama Kristen Negeri Manado. Among online lectures, the best learning process with the best lecturers according to the students will be selected as a standard for assessing the effectiveness of the learning process and lectures with follow-up. Considering that the evaluation model of Kirk Patrick has 4 levels of evaluation, that different assessments will be carried out at each level.

\section{1 Evaluation of Reaction Level}

Partner (2009) stated that the interest, attention, and motivation of the participants are critical to the success of any training program or people learn better when they react positively to the learning environment. If linked to the learning process, it can be interpreted that the result of students' positive reactions or responses are important components of the success of a learning process.

Student satisfaction on the online learning process is assessed through some aspects, including Educational Facilities, Teaching Media, Lecture Tools, Skills of lecturers, Responsiveness, and Understanding of student interests. The result of the questionnaire based on the Customer Satisfaction Index (CSI) shows that $71 \%$ of satisfaction to the online learning process. In other words, the satisfaction level is at a dissatisfied level. If calculated on each component, it is also similar. The Education Facilities, Teaching Media, and Lecture Tools components show a fairly low percentage of $66 \%$ meaning that student satisfaction on those components is at a dissatisfied level. The student satisfaction level with the skills and responsiveness of lecturers reaches $78 \%$ meaning that they are at an average level.

The interpretation of the Consumer Satisfaction Index scale can be seen in the following table:

Table 1. Interpretation of the Consumer Satisfaction Index Scale

\begin{tabular}{cc}
\hline Index Scale & Interpretation \\
\hline$x \leq 64 \%$ & Very poor \\
$64 \%<x \leq 71 \%$ & Poor \\
$71 \%<x \leq 77 \%$ & Cause for concern \\
$77 \%<x \leq 80 \%$ & Bordeline \\
$80 \%<x \leq 84 \%$ & Good \\
$84 \%<x \leq 87 \%$ & Very Good \\
$x>87 \%$ & Excellence \\
\hline
\end{tabular}

Based on the result above, it can be concluded that the online learning process is effective yet. It is because of the inadequate availability of learning facilities such as laptops/smartphones, mobile data for internet, and internet networks. In addition, competences and skills of lecturers are highly required to innovate and present learning strategies, models, 
and methods that can increase students' interest, attention, and motivation to learn in order to achieve the learning objectives.

\subsection{Evaluation of Learning Level}

In this level, the evaluation of the effectiveness of the online learning process used the Kirkpatrick model. In this level, the researcher evaluated the learning. Learning evaluation involves three aspects including attitude change, increasing knowledge, and improving skills. If all aspects cannot be fulfilled, the learning process can be said 'fail'. The evaluation of the learning level concerns the assessment of learning outcomes, so it utilized the results of student pre-test and post-test.

To calculate the comparison between the pre-test and post-test results, the researcher used the Wilcoxon Signed Rank test with the help of SPSS.

\section{Descriptive Statistics}

\begin{tabular}{l|r|r|r|r|r} 
& N & Mean & Std. Deviation & Minimum & Maximum \\
\hline Pretest & 100 & 52.8800 & 21.03258 & 20.00 & 90.00 \\
\hline Posttest & 100 & 65.5600 & 21.65539 & 25.00 & 100.00 \\
\hline
\end{tabular}

Fig.2. Descriptive Statistics

Based on the table above, the mean value of the post-test is higher than the pre-test. The significant difference can be seen from the result of the Wilcoxon Signed Rank test below.

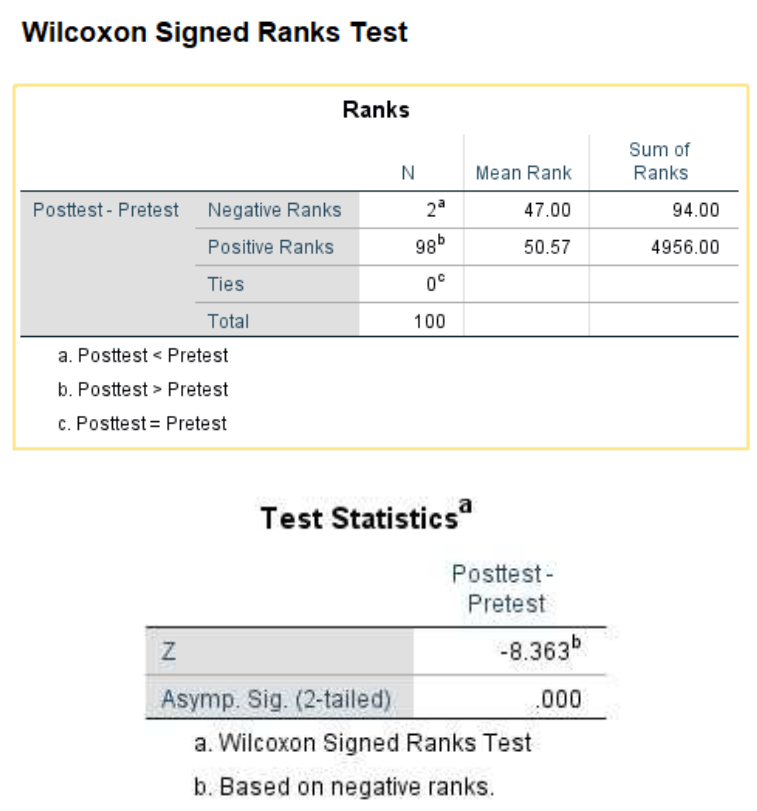

Fig.3. Wilcoxon Signed Rank Test and Test Statistics 
Based on the results of the Wilcoxon Signed Rank test, the z-value IS -8.363 with a pvalue (Asymp. Sig. 2-tailed) of 0.000 or less than the critical limit of 0.05 . Thus, the $H_{1}$ is accepted meaning that there is a significant difference between the pre-test and the post-test groups.

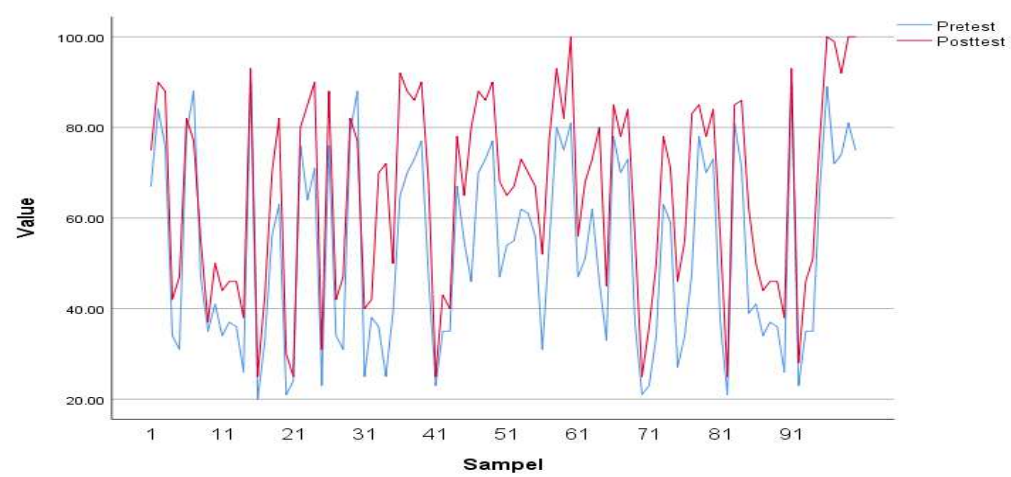

Fig.4. Histogram chart of pre-test and post-test values.

\subsection{Evaluation of Potential of Behavior Change Level}

At this level, the researcher analyzed changes or differences in student behavior after completing the online learning process. The assessment covered changes in knowledge thought, or reapplication of skills and knowledge gained during online learning to carry out activities that support the increase of value or achievement both in and outside of campus. The selected samples were students who took conditional courses which previously taught using online learning. This level used the results of assessments from the lecturers using interviews and observations. Moreover, the researcher distributed a questionnaire consisting of some categorical statements to the students.

The questionnaire was distributed to 100 students. Based on the Guttman scale, it reaches a total of $68 \%$ meaning that there is almost a change in behavior after participating in the online learning process. In other words, not all students experience behavior changes after the online learning process. However, a quick check immediately after the online learning process through the distribution of questionnaires containing categorical statements to students is not reliable because individuals change in various ways at different times. Therefore, the result of the assessment of other parties are required to be able to assess the behavior changes among students who have followed the online learning process previously.

The result of the interviews with two lecturers who took two classes of each with 25 students in each class shows that 58 out of 100 students had good basic knowledge in previous courses taught through online learning. It can be seen from the results of the quiz conducted by lecturers and assessment on how students prepare presentations independently.

\subsection{Evaluation of Result Level}

At this level, the assessment was carried out on the student's final results. The final result is the cumulative results from each component of the assessment during the learning process. If students are able to get good scores and exceed the minimum completeness criteria (KKM), it is considered a success.

The mean score of 100 students is 67.9 with a standard deviation of 10.4 . It means that the result of online learning is at a satisfactory level even though there are some students whose 
score meets the minimum standard as seen in the standard deviation value which shows that the final scores are heterogeneous.

\section{Conclusion}

Based on the result of Kirkpatrick's model, it can be concluded that the online learning process has not been effective yet because it has not met all the expectations and learning objectives. The result of the evaluation study on the online learning process indicated that some components in the online learning process need to be optimized to make the online learning process effective and able to achieve the learning objectives. Those components are supporting facilities for online learning processes, such as laptops, smartphones, mobile data for internet, and internet network access. In addition, the competence and skill of lecturers as educators in creating and presenting creative, effective, and fun learning strategies, models, and methods are crucial components of the learning process. This condition affects the process of knowledge transfer from lecturers to students and vice versa. It also automatically affects student learning outcomes and less optimum behavior changes in terms of mindset, knowledge, and application of skills and knowledge.

The researcher expects that the result of this study can provide some references to others dealing with the online learning process, particularly lecturers to be able to select the correct strategies, models, and methods to create an effective learning process and achieve learning objectives, and improve competencies and skills in implementing the online learning process to be more flexible for better results.

\section{References}

[1] Alsyaibany, R. (2019). The evaluation of effectiveness on education and training program (The Research on Diklat Increasing Added Value of Bauxite Ore Program in West Borneo). Journal of Educational and Learning Studies. 56-61

[2] Arianty, E. (2014b). Evaluasi Pendidikan Dan Pelatihan (Diklat) Model Kirkpatrick. Dipetik March 12, 2015, dari www.bppk.depken.go.id.

[3] Badu, S. Q. (2016b). Impelementasi Evaluasi Model Kirkpatrick Pada Perkuliahan Masalah Nilai Awal Dan Syarat Batas. Yogyakarta: Universitas Negeri Yogyakarta.

[4] Dewi, L. R., dan Kartowagiran, B. (2018). An evaluation of internship program by using Kirkpatrick evaluation model. Research and Evaluation in Education. 155-163

[5] Djemari Mardapin. (2000). Evaluasi Pendidikan. Makalah disampaikan pada Konvensi Pendidikan Nasional tanggal 19-23 September 2000 di Universitas Jakarta

[6] Eko Putro Widoyoko, 2010. Evaluasi Program Pembelajaran. Yogyakarta: Pustaka Pelajar Griffin, P., dan Nix, P. 1991. Educational Assessment and Reporting. Sydney: Harcout Brace Javanovich Publisher.

[7] Kirkpatrick, D. L. 1998. Evaluating Training Programs: The Four Levels. San Francisco: Berrett-Koehler Publisher, Inc.

[8] Kirkpatrick, D. L. 2005. KirkPatrick's training evaluation model. http://www.bussinesball.com/KirkPatricklearningevaluationmodel.htm.

[9] Madaus, G. F., Scriven, M. S., dan Stuffebeam, D. L. 1993. Evaluation Models, Viewpoints on Educational and Human Services Evaluation. Boston: Kluwer-Nijhoff Publishing. 
[10] Mardapi, D. 1999. Pengukuran, Penilaian, dan Evaluasi. Makalah disajikan dalam Penataran Evaluasi Pembelajaran Matematika SLTP untuk Guru Inti Matematika di MGMP SLTP, PPPG Matematika Yogyakarta, Yogyakarta, 8-23 November.

[11] Marfuah, U., dkk. (2016). Pengukuran tingkat kepuasan mahasiswa terhadap pelayanan akademik fakultas X Universitas XYZ. Jurnal UMJ. Seminar Nasional Sains dan Teknologi.

[12] Naugle. 2005. KirkPatrick's evaluation model as a means of evaluating teacher performance. http://www.findarticles.com/p/articles

[13] Oriondo, L. L., dan Antonio, E. M. D. 1998. Evaluating Educational Outcomes (Test, Measurment, and Evaluation). Florentino St: Rex Printing Company.

[14] Popham, W. J. 1995. Classroom Assessment. Boston: Allyn and Bacon.

[15] Wong, P.-m., \& Wong, C.-s. (2015). The Evaluation Of A Teacher Training Program In School Management. SAGE Publications, 385-401 